\title{
Valorization of the Use of Calcareous Tuff and Dune Sand in Saharan Road Design
}

\author{
Messaouda Cherrak ${ }^{1,2}$, Meriem Morsli $^{1}$, Ramdane Boutemeur $^{1}$ and Abderrahim Bali ${ }^{1}$ \\ 1. Laboratory Construction and Environment, National Polytechnic School, Algiers 16000, Algeria \\ 2. Department of Civil Engineering, University of Blida, Blida 09000, Algeria
}

\begin{abstract}
This research objective is to propose a co-valorization of powdered tuff, containing a slight amount of clay and dune sand, by mixing the two substances at different rates such as $0 \%, 5 \%, 15 \%, 25 \%$ and $35 \%$ of sand. The adapted criteria formulas are those recommended by the technical Saharan road. The results of the proposed study showed that "tuff-sand" mixtures are denser with a lower optimum water content modified proctor, the fine rate decreases together with the plasticity index, whereas the bearing index (CBR: California bearing ratio test) increases. The intrinsic characteristics, cohesion and sensitivity of mixtures with respect to compactness are almost identical to those of tuff without addition. The optimal adapted sand incorporation rate is estimated at $25 \%$ at $96 \%$ of compactness. Under these conditions, the amount of fines decreases from $40 \%$ to an acceptable level of $25 \%$ and the plasticity index from 16.2 to 12 . The compaction water content decreases by $36 \%$ and the CBR (bearing index) increases by $30 \%$ and the compressive strength and sensitivity, according to compactness, of the elaborated material are almost identical to those of tuff without addition.
\end{abstract}

Key words: Tuff, dune sand, road construction, CBR, water content, consolidated drained triaxial test.

\section{Introduction}

Algerian Sahara area is about 2 million $\mathrm{km}^{2}$. It consists of nearly $40 \%$ of desert mountains, $15 \%$ of desert plains and about $30 \%$ of dune sand, the rest being sebkhas and chotts, and covers about a third of the African continent [1]. Locally available materials are mainly crusting tuffs, crashed sand, granitic arena, silt, clay and dune sand. Conventional aggregate resources are virtually nonexistent [2-3]. However, for nearly half a century, thousands of kilometers of economic roads for region development have been successfully built, using mainly crusting tuffs. These alternative materials are extracted from limestone, gypsum or gypsum-limestone deposits. Calcareous crusts are located in the semi-arid regions (where only from $100 \mathrm{~mm}$ to $350 \mathrm{~mm}$ of rain per year is recorded), gypsum crusts are located in the hyper-arid areas (less than $100 \mathrm{~mm}$ of rain per year), whereas the

Corresponding author: Messaouda Cherrak, Ph.D. student, research fields: valorization of local materials and geotechnique. E-mail: messaoudacherrak@yahoo.fr. gypsum-calcareous crusts can be found within the intermediate zones. All these formations constitute the geographical area spreading from North to South Sahara [4-5].

The good performance of roads built from these tuffs can be attributed to the characteristics of these materials, favorable environmental conditions (soil quality support and rainfall conditions) [6], recommendations of the technical Saharan road and expertise of road technicians [7-10]. Research works have been conducted to better benefit from the advantages offered by these materials [11-15]. Their essential particularity comes from the cohesion derived from the reciprocal affinity of the powdered elements from limestone and gypsum, after compaction and drying. They also have the singular property to harden with age without treatment [16-17]. This curing can be explained by the dissolution of a part of the carbonated fines and gypsum in compaction water by a re-crystallization during the evaporation of the latter giving rise to local cemented 
links [18]. This same process is also behind the formation of crusts from which are extracted tuffs [5].

It is this hardening, also called self-stabilizing, which allowed the use of the crusting tuffs in road pavements, despite the geotechnical characteristics that deviate from the usual specifications for temperate countries. However, tuffs are too sensitive to water and energy compaction, indeed, hardening disappears almost entirely by imbibitions and performances drop significantly for slight decrease in compaction rate. Moreover, a high percentage of fines (> 30\%) causes, during the compacting process, a foliation phenomenon making the material unusable in road construction [19-22].

Although dune sand is available in abundance in southern Algeria, there remains a material that has very poor mechanical properties. It is characterized by a granular and mineralogical composition almost similar over the whole desert: $95 \%$ silica at least, $1 \% \sim 2 \%$ limestone and traces of various oxides. The diameters of the coarser and the finer grained elements are about $0.5 \mathrm{~mm}$ and $0.04 \mathrm{~mm}$, respectively. The uniformity coefficient (ratio of the sieve meshes size for which there are respectively $60 \%$ and $10 \%$ passing $C u=\mathrm{D} 60 / \mathrm{D} 10)$ and the coefficient of curvature (ratio of sieve meshes size at $30 \%, 10$ and $60 \%$ passing, defined by $C c=$ D230/D10.D60) are of the order of 1.8 and 10 , respectively. It is therefore very poorly graded sand. It contains substantially no traces of clay. It has a liquid limit $(W l)$ of about 25 and a plastic limit which cannot be measured. The value of the sand equivalent is greater than $60 \%$. The blue value is around 0.1 . Cohesion is almost 0 , the bearing index at the optimum values of the modified proctor test is very low [23]. All these characteristics make it difficult to use as a construction material without pre-treatment [24-25]. Its valorization has been the subject of several investigations such as: stabilization of clays, dune sand concrete formulation, mortar and high performance concrete [26-32].

In road construction, stability of dune sand can be obtained by "blocking" the grains against each other, and the quality of this block is variable. Consideration may be given either to be a simple setting of the grains by incorporation of a finer substance (fly ash and paper mud) that fills the voids, or to a setting and stiffening by techniques such as "sand-paper mud-cement, sand-fly ash-cement and sand-fly ash-lime" or to a single stiffening by hydraulic setting (sand and hydraulic binder), or by thermal setting (sand-bitumen) [33-38]. A co-valorization of mixed material, having complementary characteristics, is also possible [39-40].

\section{Characterization of Studied Materials}

Both studied materials come from the region of southern Algeria: Béchar for tuff and Ouargla for dune sand. Geotechnical identification of tuffs as currently practiced in Algerian road laboratories is performed according to accepted classical geotechnical standards, however, with some modifications according to the recommendations of the Saharan Road techniques:

- The determination of the percentage of gypsum and/or limestone is performed on the particle size fraction smaller than $1 \mathrm{~mm}$;

- Particle size distribution is performed on a sample that has been put to soak in a tank of water for $12 \mathrm{~h}$ to $24 \mathrm{~h}$;

- A rough metal cup is recommended for determining the Atterberg limits.

- During compaction tests (proctor test), we do not reuse the same sample for different water content levels;

- The blue test aims to determine the fine activity and determine the presence of the clay. It is performed on the fraction $0 \sim 2 \mathrm{~mm}$ according to NF P 94-068. The result is the VB (blue vage), expressed as $\mathrm{g}$ of methylene blue absorbed by $100 \mathrm{~g}$ of material;

- The CBR (California bearing ratio) test is a punching shear. It is retained in the specifications of many countries [40]. It is performed according to the 
procedure of the standard NF P 94-078. This test is used to define a bearing index $I_{C B R}$. Practically, for a given soil, the bearing index $I_{C B R}$ is the greater of two values: pressure at $2.5 \mathrm{~mm}$ of sinking/0.7; pressure at $5 \mathrm{~mm}$ of sinking/1.05.

Cohesion is appreciated by simple compression test performed on samples prepared in cylinder moulds of $50 \mathrm{~mm}$ diameter and $100 \mathrm{~mm}$ height with materials having a granularity $0 \sim 5 \mathrm{~mm}$. Compaction is done statically using a compressive bearing press with

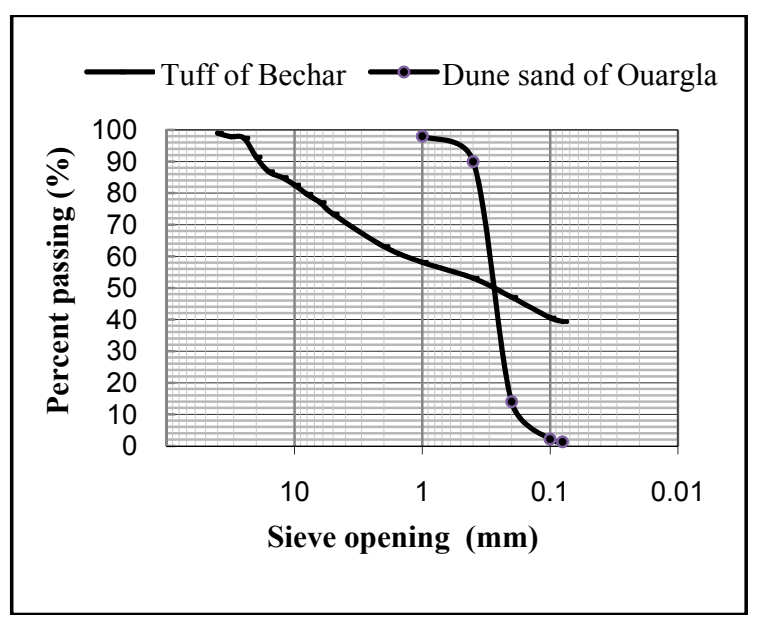

Fig. 1 Grading curves of dune sand and tuff. a speed of $1.25 \mathrm{~mm} / \mathrm{min}$ at different compactness values, at the optimum water content for the modified proctor test. The readings are recorded every $15 \mathrm{~s}$.

The results of chemical, geotechnical and mechanical identification are summarized in Figs. 1, 2 and Table 1.

\section{Methodology}

In order to enhance the properties of the studied materials, a co-valorization of both particles at different rates has been conducted.

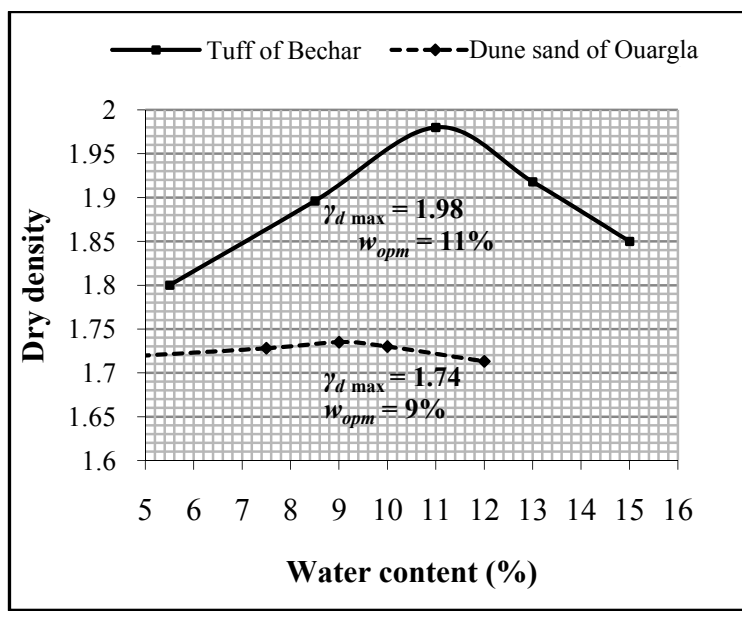

Fig. 2 Proctor curves of dune sand and tuff.

Table 1 Physical and mechanical characteristics of tuff of Bechar and dune sand of Ouargla.

\begin{tabular}{|c|c|c|}
\hline & Tuff of Bechar & Dune sand of Ouargla \\
\hline \multicolumn{3}{|l|}{ Chemical composition } \\
\hline Limestone $\mathrm{CaCO}_{3}(\%)$ & 81.64 & Traces \\
\hline Silica $\mathrm{SiO}_{2}(\%)$ & 17 & 86 \\
\hline \multicolumn{3}{|l|}{ Particle size distribution: NF: P 94-056 and NF: P61-057 } \\
\hline$d / D$ & $0 / 20$ & $0.2 / 0.4$ \\
\hline$<80 \mu \mathrm{m}(\%)$ & 40 & 1.3 \\
\hline Coefficient of uniformity: $C u(\%)$ & - & 1.5 \\
\hline Coefficient of Hzen (curvature): $C z(\%)$ & - & 11 \\
\hline Coefficient of Los Angeles (NF 18-573): LA (\%) & 55 & - \\
\hline \multicolumn{3}{|l|}{ Atterberg limits: NF: 94-051 } \\
\hline Limits of liquidity : $W l$ & 40 & 23 \\
\hline Limit of plasticity: $W p$ & 23.8 & - \\
\hline Plasticity index: $I p$ & 16.2 & - \\
\hline Sand equivalent (NF P 18-598): ES (\%) & 4.83 & 81.2 \\
\hline Blue value (NF P 94-068): $V B$ & 0.75 & 0.1 \\
\hline \multicolumn{3}{|l|}{ Compaction and bearing : NF P 94-093 et 078} \\
\hline Optimum water content: $W_{\text {opm }}(\%)$ & 11 & 9 \\
\hline Maximum dry density: $\gamma_{\text {opm }}$ & 1.98 & 1.74 \\
\hline Bearing index $I_{C B R}$ after soaking (\%) at $95 \%$ compactness & 20 & 5 \\
\hline Compressive strength (MPa) at 95\% compactness & 13.9 & 0 \\
\hline
\end{tabular}


The objective of the procedure is for better understanding the assessment of the geotechnical and mechanical characteristics of the "tuff-sand" mixtures. The judging criteria for the elaborated mixture are given by the order of priority [8]:

- a minimum amount of fines;

- a minimum plasticity;

- a maximum density;

- a maximum bearing capacity;

- a maximum strength.

The study will be conducted in the range (95\% to $98 \%$ ) of usual compactness used on site. As a reminder, the compactness is the ratio of the material density in place to the modified proctor maximum dry density.

Tests have been carried out on mixtures incorporating $0 \%, 5 \%, 15 \%, 25 \%$ and $35 \%$ of dune sand, respectively.

The percentage of fine, the sand equivalent, the methylene blue test value and plasticity index have been estimated for each incorporation rate of sand.

Modified proctor curves are plotted for each incorporation rate of sand and the proctor characteristics are identified.

The samples have then been prepared using the optimum water content modified proctor of each mixture but at different theoretical compactness rates, notably at $95 \%, 96 \%, 97 \%$ and $98 \%$. The proctors values are determined for each incorporation rate of sand, considering an average of three specimens. The true compactness values are then evaluated for each specimen tested.

The experimental curves are plotted against true compactness of specimens. Tuff only and optimal mix of tuff with sand dune shall be subject to a consolidated drained triaxial test.

The analyses of the results and discussions are made on the basis of the curves deducted from experimental graphs.

The mechanical performances are analyzed according to the rate of incorporation rate of sand and the compactness rate.

\section{Experimental Results}

\subsection{Rate of Fines and Clay Content in Mixtures}

The incorporation of dune sand has lowered the plasticity index, the percentage of fines, the sand equivalent and the blue value (Figs. 3a-3d). All these indices have been evolved in a way to promote the compaction of mixtures.

\subsection{Ability of Mixtures to Compaction}

Addition of dune sand moves the modified proctor curves to the left (Fig. 4) with an improvement of the optimal characteristics: reduction of water content and increase in dry density (Figs. 5 and 6). This behavior is similar to the classic behavior of materials compacted at different energies [41].

This phenomenon may be explained by the reduction of fines and their replacement by particles which, due to their shape and size, facilitate their movement by directing them in order to form a denser structure.

Beyond certain amount ( $25 \%$ in our case), dune sand no longer plays the role of lubricant and aims to replace the basic material by imposing its own characteristics. Eventually, the density should tend towards those of sand.

\subsection{Bearing Index Evolution $\left(I_{C B R}\right)$}

Bearing index, according to compactness, presents a linearity in results. This linearity has been confirmed by trend curves of Fig. 7 and equations of Table 2 .

The elaborated "sand dune-tuff" material is as sensitive as the tuff without additions at different compaction rates: a compactness drop from $98 \%$ to $95 \%$ results in a decrease in the bearing index of $38 \%$ or up to $40 \%$ with mixture containing $35 \%$ of sand. The incorporation of sand does not attenuate the close dependency between the bearing and the compaction rate. 


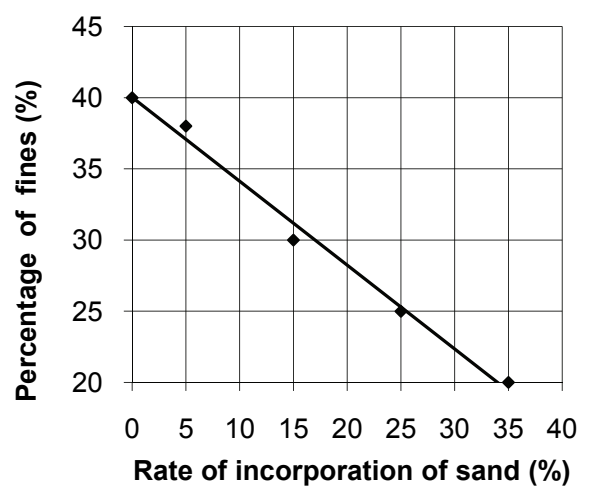

(a)

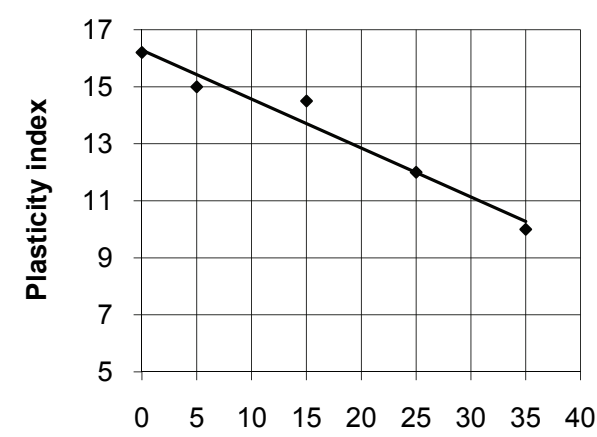

Rate of incorporation of sand (\%)

(c)

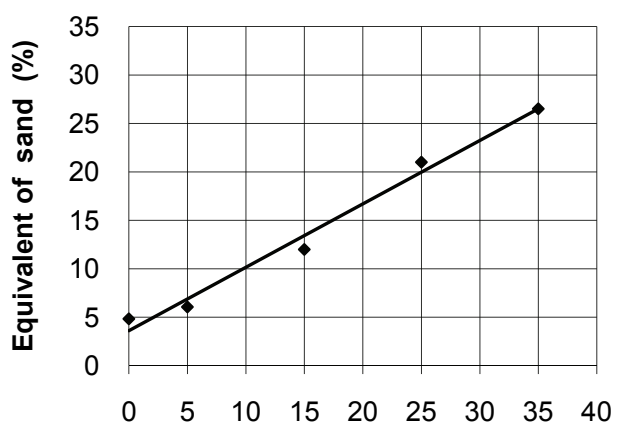

Rate of incorporation of sand (\%)

(b)

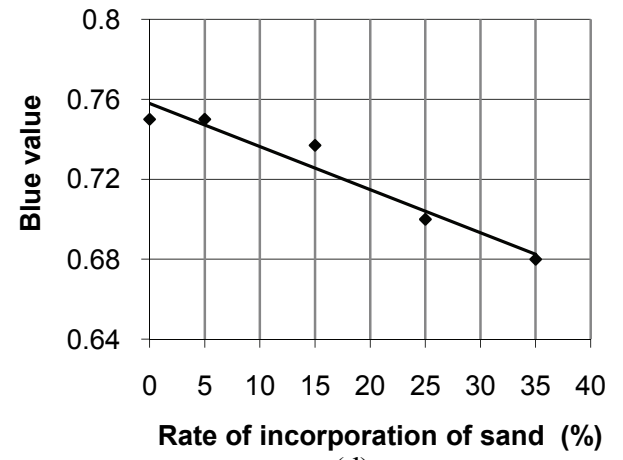

(d)

Fig. 3 Evolution of the characteristics of the mixtures according to the rate of incorporation of sand: (a) evolution of the percentage of fines; (b) evolution of the sand equivalent; (c) evolution of the plasticity index; (d) change in the methylene blue test value.

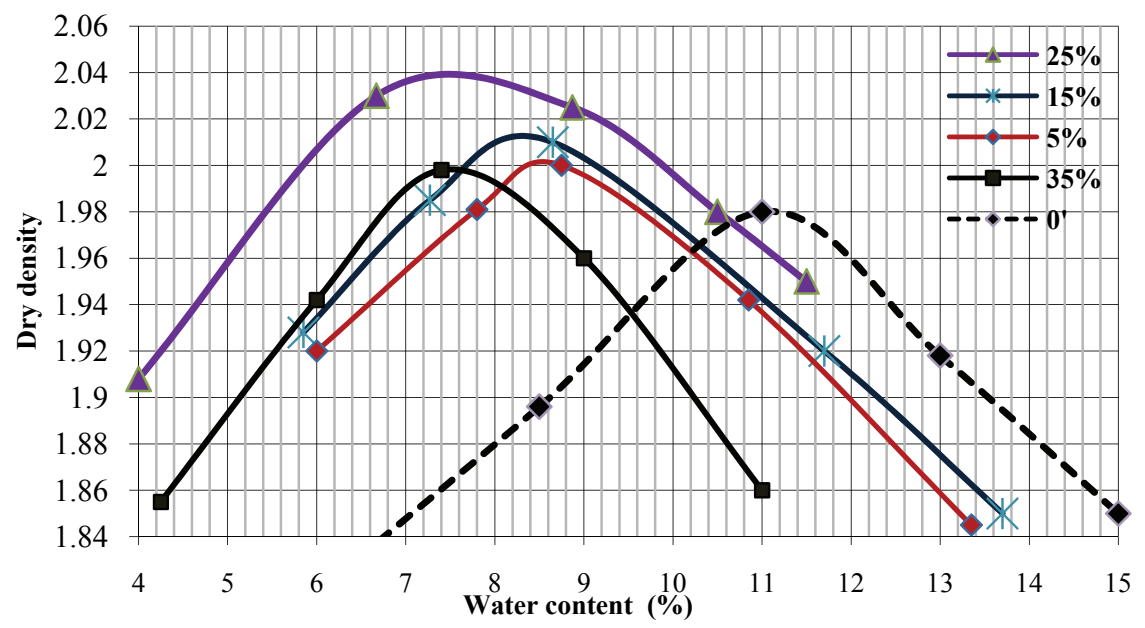

Fig. 4 Influence of the addition of sand on modified proctor curves.

For influence of the incorporation rate of sand on the bearing index, to understand the evolution of the bearing index according to the incorporation rate of sand, curves have been plotted (Fig. 8) based on the results of Table 2.
It should be noted that, in general, the addition of sand improves the bearing index whatever the compactness. However, the shape of the curves is different from that of compression strength (Figs. 9 and 10). 


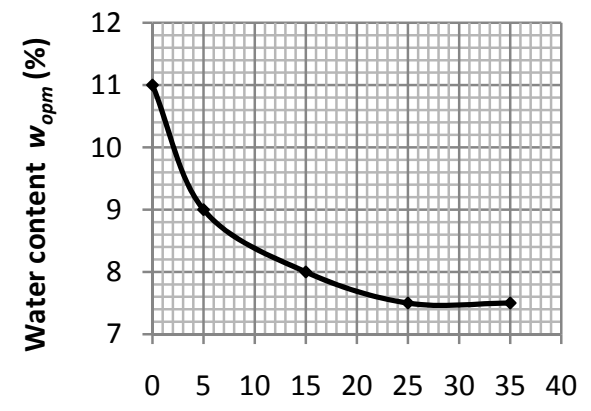

Rate of incorporation of sand (\%)

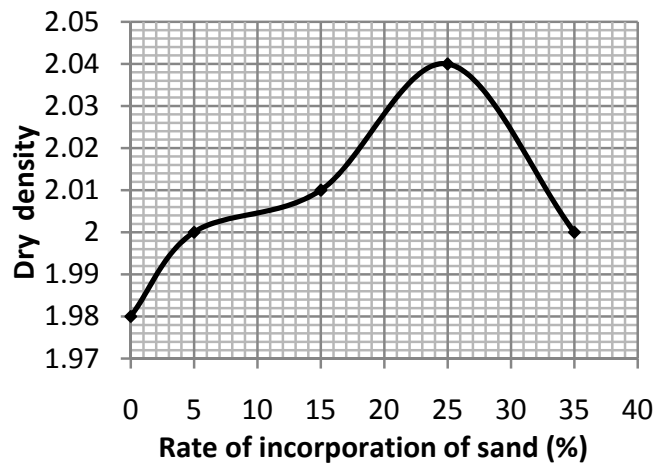

Fig. 6 Variation of maximum dry density according to the incorporation rate of sand.

Fig. 5 Variation of the compaction water content.

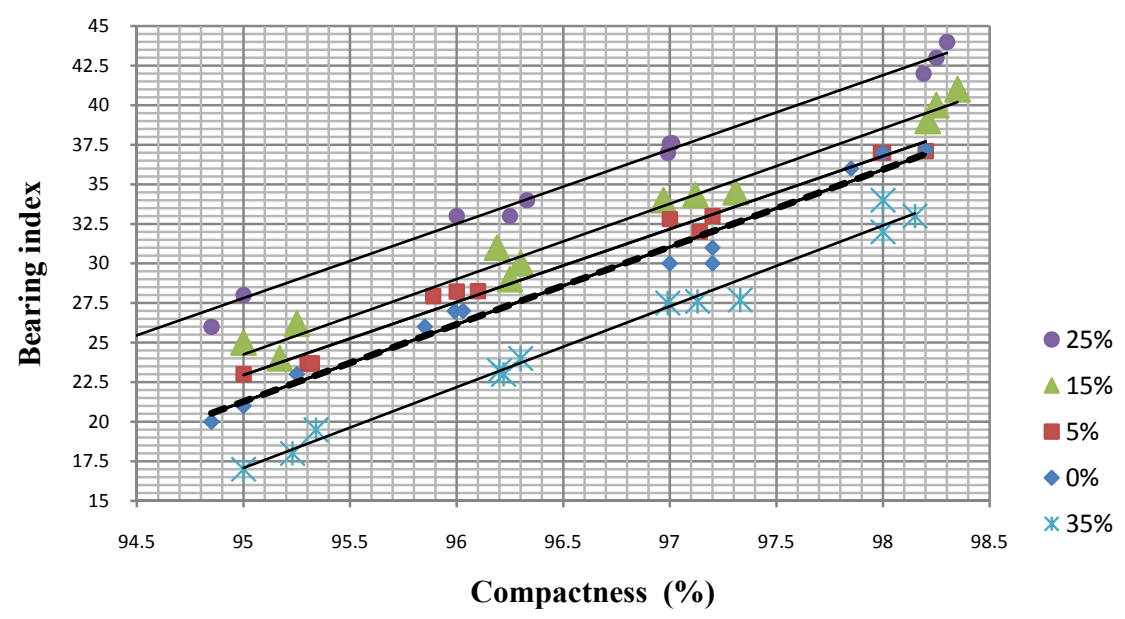

Fig. 7 Evolution of bearing index of mixtures according to compactness.

Table 2 Equations of trends curves and bearing indices at different compactness rates.

\begin{tabular}{lclllll}
\hline \multirow{2}{*}{$\begin{array}{l}\text { Sand } \\
(\%)\end{array}$} & \multirow{2}{*}{ Equations of trends curves } & \multicolumn{4}{c}{ Bearing index $I_{C B R}$ at different compactness rates } & \multirow{2}{*}{$\left(I_{C B R 98}-I_{C B R 95}\right) / I_{C B R} 98$} \\
\cline { 3 - 6 } & & $95 \%$ & $96 \%$ & $97 \%$ & $98 \%$ & \\
\hline $0 \%$ & $I_{C B R}=4.889 C^{*}(\%)-443.2 ; R^{2}=0.973$ & 21.25 & 26.14 & 31 & 35.92 & $41 \%$ \\
$5 \%$ & $I_{C B R}=4.613 C(\%)-415.3 ; R^{2}=0.987$ & 22.93 & 27.54 & 32.16 & 36.77 & $38 \%$ \\
$15 \%$ & $I_{C B R}=5.362 C(\%)-486.8 ; R^{2}=0.991$ & 22.59 & 27.95 & 33.31 & 38.67 & $41 \%$ \\
$25 \%$ & $I_{C B R}=4.694 C(\%)-418.1 ; R^{2}=0.990$ & 27.83 & 32.52 & 37.22 & 41.91 & $34 \%$ \\
$35 \%$ & $I_{C B R}=5.110 C(\%)-468.3 ; R^{2}=0.985$ & 17.15 & 22.26 & 27.37 & 32.48 & $47 \%$ \\
\hline
\end{tabular}

*: designed compactness rate.

For this test, the punching is done after imbibitions without previous drying: the hardening phenomenon does not occur. A new arrangement of the grains can justify this gain in bearing capacity.

Indeed, up to $25 \%$ of addition, the sand plays a particle size corrector role and/or plasticizer, reducing the amount of water compaction, improving the dry density and reducing the clay content and the fines percent which constitutes elements to the improvement of the bearing mixtures (Fig. 8).

Beyond $25 \%$ of addition, the characteristics of the sand are beginning to emerge, leading to a significant decrease in bearing index.

\subsection{Compressive Strength}

\subsubsection{Compressive Strength According to} Compactness

All curves are upward: strength increases almost 


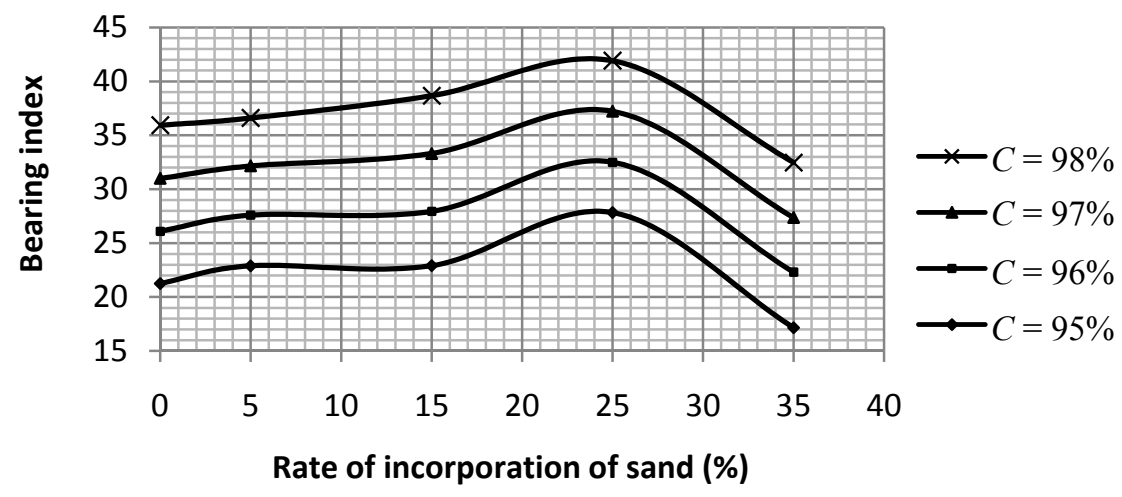

Fig. 8 Influence of the incorporation rate of sand on the bearing index at different compactness rates.

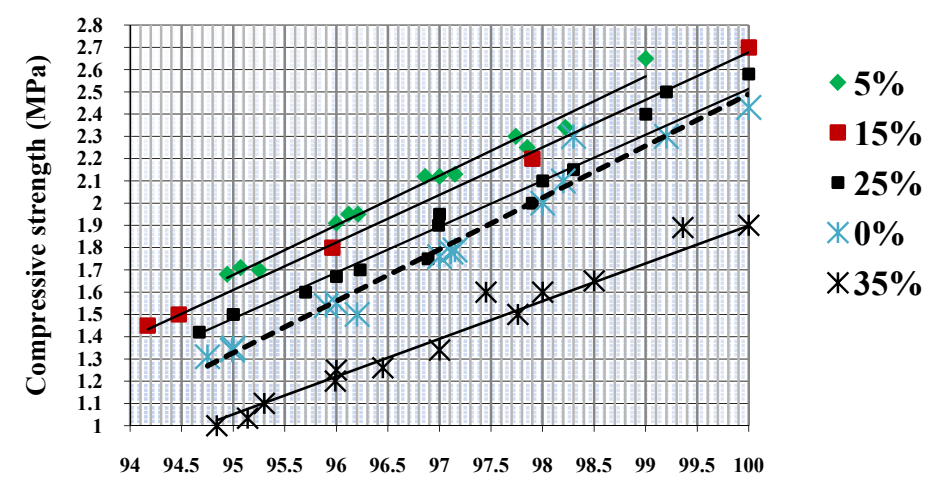

Compactness (\%)

Fig. 9 Influence of compactness on compressive strength.

Table 3 Equations of trends curves of strength at different compactness rates.

\begin{tabular}{lcccccc}
\hline \multirow{2}{*}{$\begin{array}{l}\text { Sand } \\
\text { \%) }\end{array}$} & \multirow{2}{*}{ Equations of trends curves } & \multicolumn{4}{c}{ Compressive strength $R_{C}$ at different compactness rates } & \multirow{2}{*}{$\left(R_{C 98}-R_{C 95}\right) / R_{C 98}$} \\
\cline { 3 - 6 } & & $95 \%$ & $96 \%$ & $97 \%$ & $98 \%$ & $35 \%$ \\
\hline $0 \%$ & $R_{C}=0.232 C \%-20.76 ; R^{2}=0.995$ & 1.28 & 1.51 & 1.74 & 1.98 & $29 \%$ \\
$5 \%$ & $R_{C}=0.223 C \%-19.52 ; R^{2}=0.983$ & 1.66 & 1.89 & 2.11 & 2.33 & $29 \%$ \\
$15 \%$ & $R_{C}=0.213 C \%-18.67 ; R^{2}=0.985$ & 1.56 & 1.78 & 2.00 & 2.20 & $30 \%$ \\
$25 \%$ & $R_{C}=0.206 C \%-18.13 ; R^{2}=0.985$ & 1.44 & 1.65 & 1.85 & 2.05 & $33 \%$ \\
$35 \%$ & $R_{C}=0.169 C \%-15.06 ; R^{2}=0.982$ & 1.00 & 1.16 & 1.33 & 1.50 & 30 \\
\hline
\end{tabular}

linearly with compactness for all studied incorporation rates of sand (Fig. 9 and Table 3).

The addition of sand did not reduce this dependence. A decrease of about $30 \%$ in the compressive strength has been observed for a decrease in compactness of 3\% (Table 3).

4.4.2 Influence of the Amount of Sand Addition on Compressive Strength

All curves have the same shape (Fig. 10). They all pass through a maximum at $5 \%$ addition of sand. Up to an amount of $25 \%$ of sand incorporation, the considered curves are all situated above the straight line representing the strength of tuff without addition monitored at $95 \%$ of compactness.

It should be noted that, at $5 \%$ of incorporation, the grains of sand do not seem to affect the particular property of tuff for developing cohesion after compaction and drying. However, they play a role of plasticizer and a water reducing admixture: the compaction optimum water content is less than that of the tuff without addition, i.e.: $w_{\text {opm }}$ (tuff sand $+5 \%$ ) $=$ $w_{\text {opm }}$ (tuff without addition) $-2 \%$. In fact, this amount 
of water is corresponding to the optimum water content which develops the maximum cohesion of the material [18]. This situation has been repeated at different compactness rates leading to a strength variation between 1.7 $\mathrm{MPa}$ and 2.33 $\mathrm{MPa}$. Beyond 5\%, the compaction water content decreases and becomes insufficient to ensure the dissolution of part of the carbonated fines necessary for the development of local cemented links which lead to a gradual decrease of the strength.

When the rate of sand reaches significant values $(>$ $25 \%$ ), the decrease in compaction water content and the reduction of carbonate fines replaced by dune sand particles combine to contribute towards significantly reducing the cohesion of mixtures $[13,16,21]$.

\subsection{Triaxial Test}

We conducted a consolidated drained triaxial test
"CD" because, for pavement, material is the static long-term behavior that is most important. Indeed, the loads applied in permanence produce consolidation and water drainage is required for the durability of roads. For a more realistic representation of this, consolidated drained test best reflects reality. In these conditions, the effective stresses are equal to the total stress. Consolidation is under hydrostatic pressure $\left(\sigma_{1}=\sigma_{2}=\sigma_{3}\right)$ for each specimen, and the stress $\sigma_{3}$ which was used for consolidation will be kept constant during loading to failure.

The specimens destined for the triaxial test are made with tuff granularity $0 / 5 \mathrm{~mm}$. These are cylindrical samples of $5 \mathrm{~cm}$ in diameter and $10 \mathrm{~cm}$ in height. They were statically compacted under optimal conditions $\left(\gamma_{d}, w_{\text {opm }}\right)$ under the hydrostatic pressures at 1,2 and 3 bars. This compaction is achieved by a press of a CBR type traveling speed equal to $1.27 \mathrm{~mm} / \mathrm{min}$.

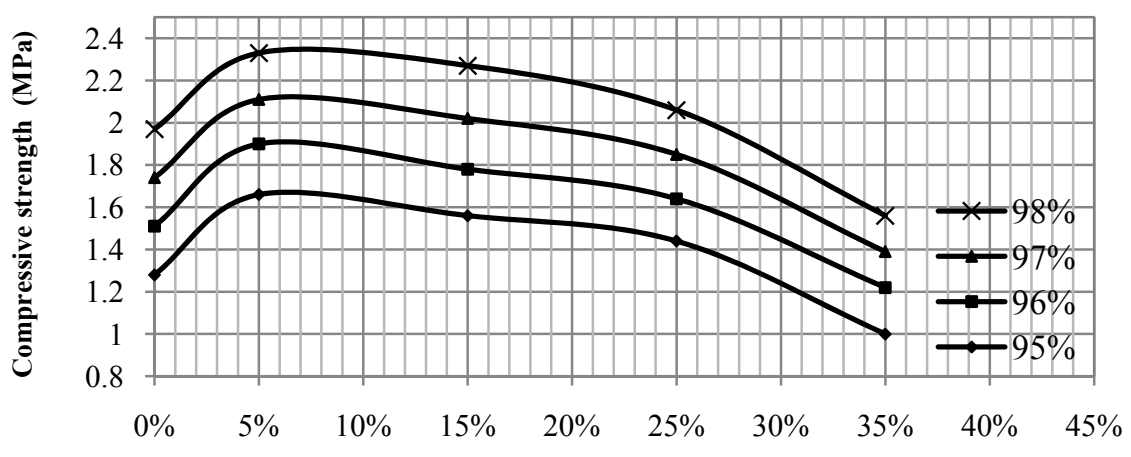

Rate of incorporation of sand

Fig. 10 Influence of sand addition rate on compressive strength at different compactness rates.

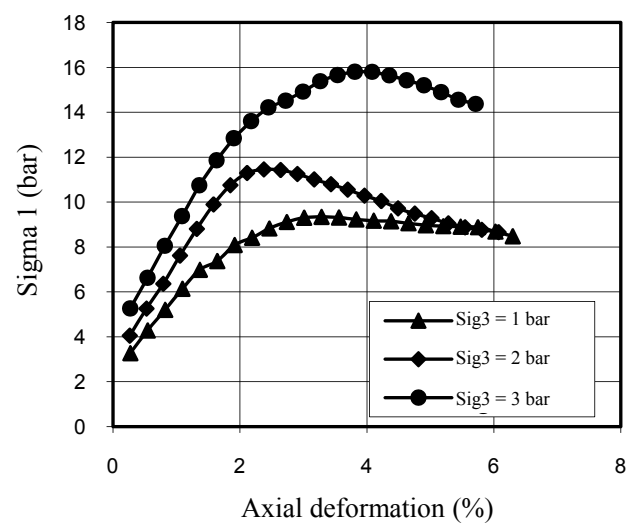

(a)

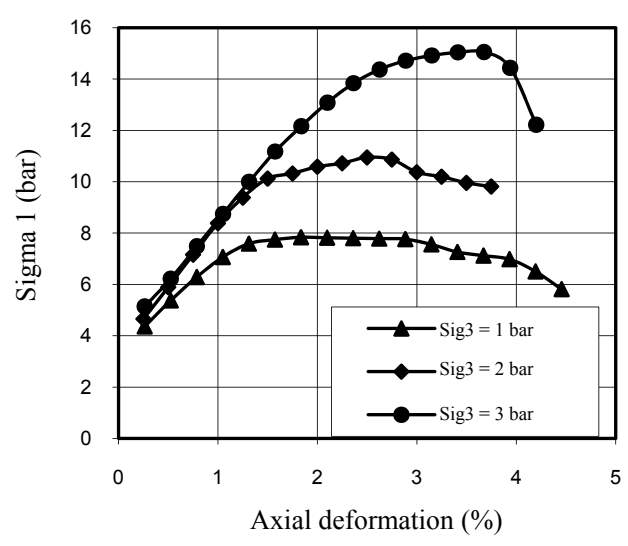

(b)

Fig. 11 Stress-strain curves: (a) tuff of Bechar; (b) tuff of Bechar $+25 \%$ of dune sand. 
Fig. 11 shows the curves "stress-strain" at different lateral stresses $\left(\sigma_{3}\right)$ only tuff of Bechar and mixed with $25 \%$ sand dune Ouargla.

Studying these curves shear, we notice a nonlinear elastic deformation and plastic deformation. So we can assign an elastoplastic behavior in the tuff. The triaxial test allows us to determine the shear strength which is expressed in terms of cohesion $C$, friction angle $\varphi$ and the normal stress $\sigma$ to the fracture surface by Coulomb's law: $\tau$ (shear strength) $=C+\sigma \tan \varphi$. The results of $C$ and $\varphi$ obtained for only tuff and tuff with $25 \%$ of dune sand are summarized in Table 4 . There are also values of conventional materials used to make comparisons.

Comparing intrinsic characteristics of our samples (tuff and tuff $+25 \%$ sand dune) with constants other road conventional materials, we deduced that:

- The internal friction angles of our samples are slightly lower than those of other materials;

- The cohesions of our two samples are much higher compared to other materials. This strong cohesion is explained by the presence of a significant percentage of fines in the tuff. This specificity provides our base material to withstand higher loads in the case of low stress, and this justifies the good performance of pavements built in tuff low and medium traffic;

- As regards the effect of the addition of sand dune on the intrinsic characteristics of the base material, it was observed an increase of the friction angle of $1.5^{\circ}$ and a decrease in cohesion of 0.3 bars. It was predictable that the sand has no cohesion and with an angle of friction greater than that of other materials.

\subsection{Recapitulation of the Main Characteristics of the Mixtures}

The main characteristics are listed in Table 5.

From the analysis of the obtained results, it should be noted that the most appropriate formula is that containing an amount of $30 \%$ of sand at the condition to reach a compactness of $98 \%$.

Table 4 Shear properties of tuff, tuff $+\mathbf{2 5 \%}$ sand dune and conventional materials.

\begin{tabular}{llllll}
\hline & Tuff & Tuff $+25 \%$ dune sand & Crushed grave & Corrected grave & Rolled grave \\
\hline$C$ (bars) & 1.3 & 1 & 0.68 & 0.20 & 0.16 \\
$\varphi$ (degree) & 34.69 & 36.25 & 53 & 47 & 45.5 \\
\hline
\end{tabular}

Table 5 Geotechnical and mechanical characteristics of different mixtures.

\begin{tabular}{|c|c|c|c|c|c|c|c|c|}
\hline \multicolumn{2}{|l|}{ Incorporation rate of sand } & $\begin{array}{l}0 \% \\
\text { (tuff) }\end{array}$ & $5 \%$ & $15 \%$ & $25 \%$ & $35 \%$ & $\begin{array}{l}100 \% \\
\text { (sand) }\end{array}$ & $T R S^{*}$ \\
\hline \multicolumn{2}{|l|}{ Optimum dry density } & 1.98 & 2.00 & 2.01 & 2.10 & 2.00 & 1.74 & $>1.70$ \\
\hline \multicolumn{2}{|l|}{ Optimum water content (\%) } & 11 & 9 & 8 & 7.5 & 7.5 & 9 & - \\
\hline \multicolumn{2}{|l|}{ Fines content $(\%)$} & 40 & 38 & 30 & 25 & 20 & 0 & $<30 \%$ \\
\hline \multicolumn{2}{|l|}{ Sand equivalent (\%) } & 4.83 & 5 & 6 & 12 & 24 & 81.2 & - \\
\hline \multicolumn{2}{|l|}{ MBT (methylene blue test) value } & 0.75 & 0.74 & 0.73 & 0.70 & 0.68 & 0.1 & - \\
\hline \multicolumn{2}{|l|}{ Plasticity index $(\%)$} & 16.2 & 15 & 14 & 12 & 9.5 & 1 & $<13$ \\
\hline \multirow{4}{*}{$\begin{array}{l}\text { Compressive strength } R_{C} \text { at } \\
\text { different compactness rates } \\
(\mathrm{MPa})\end{array}$} & $95 \%$ & 1.28 & 1.66 & 1.55 & 1.44 & 1 & 0 & \multirow{4}{*}{$>1.50$} \\
\hline & $96 \%$ & 1.51 & 1.89 & 1.78 & 1.65 & 1.16 & 0 & \\
\hline & $97 \%$ & 1.74 & 2.11 & 2.00 & 1.85 & 1.33 & 0 & \\
\hline & $98 \%$ & 1.98 & 2.33 & 2.20 & 2.05 & 1.50 & 0 & \\
\hline \multirow{4}{*}{$\begin{array}{l}\text { Bearing index } I_{C B R} \text { at different } \\
\text { compactness rates }\end{array}$} & $95 \%$ & 21.25 & 22.89 & 22.90 & 27.87 & 17.15 & - & \multirow{4}{*}{-} \\
\hline & $96 \%$ & 26.1 & 27.6 & 27.95 & 32.5 & 22.3 & - & \\
\hline & $97 \%$ & 31 & 32.16 & 33.31 & 37.22 & 27.37 & 5 & \\
\hline & $98 \%$ & 35.92 & 36.6 & 38.67 & 41.91 & 32.48 & - & \\
\hline
\end{tabular}

*Thresholds imposed by the TRS. 
However, at $25 \%$ of addition and for a reasonable compactness of $96 \%$, the formula may also be acceptable, where the values of the experimental results are conformed to thresholds imposed by the TRS (Technical Saharan Road), given in the last column of Table 5. Under these conditions, the amount of fines goes from $40 \%$ to a reasonable content of $25 \%$ and the plasticity index from 16.2 to 12 . Whereas, the compaction water content decreases by $36 \%$ and the bearing index increases by $30 \%$. The intrinsic characteristics $(C, \varphi)$, compressive strength and sensitivity of the elaborated material according to compactness are almost identical to those of tuff with no sand incorporation.

\section{Conclusions}

The co-valorization based on a simple mixture of dune sand and a calcareous tuff matches with a basis principle in road engineering which consists of using a maximum of local materials.

The incorporation of dune sand improves the density and bearing capacity of mixtures and these characteristics remain however dependent on the compactness.

The optimum proportioning material mix consists of $75 \%$ of tuff and $25 \%$ of dune sand for a compactness of $96 \%$.

This mix content may be changed to $70 \%$ of tuff and $30 \%$ of dune sand provided to ensure compaction of the elaborated material that guarantees up to $98 \%$ of modified proctor density.

An adapted stabilization of the elaborated material tuff-dune sand may allow increasing sand content in the mixture.

This study could be extended to other types of tuffs in order to identify factors influencing the optimal rate of incorporation of dune sand.

The material placing and the long-term behavior of the tuff-dune sand mixture must be investigated in order to elaborate a procedure standard.

The stabilization technique by incorporating dune sand opens perspectives that will enhance local materials in areas without conventional materials.

\section{References}

[1] Fooks, P. G., and Higginbothman, I. E. 1968. "Problem of Construction Aggregates in Desert Areas with Particular Reference to the Arabian Peninsula." In Proceedings of Institution of Civil Engineers, 39-67.

[2] Morsli, M., Kettab, R., Bali, A., and Fleureau, J. M. 2002. "Prospection des Matériaux Sahariens (Prospecting Saharan Materials)." Presented at Journées Nationales de Géotechnique et de Géologie de l'Ingénieur (Geotechnical National Days and Engineering Geology), Nancy. (in French)

[3] Morsli, M., Kettab, R., Bali, A., and Fleureau, J. M. 2000. "Valorisation des Matériaux Locaux (Valorisation of Local Materials)." Presented at International Conference Geo Engineering, University of Science and Technology Houari Boumerdienne, Algiers. (in French)

[4] Djili, K., Daoud, Y., and Ayache, N. 1999. "Analyse de la Distribution Verticale et Spatiale du Calcaire Dans les Sols de l'Algérie Septentrionale (Analysis of the Vertical and Spatial Distribution of Limestone in the Soil of Northern Algeria)." Revue Etude et Gestion des Sols 6 (3): 201-13. (in French)

[5] Guettouche, M. S., Guendouz, M., and Boutiba, M. 2006. "Sur l'Existence d'un Modèle-Type d'Encroûtements des Sols Arides et Semi-arides d'Algérie (The Existence of a Model Type of Arid and Semi-arid Crusts Soils in Algeria)." Journal des Sciences Pour l'Ingénieur 6: 65-80. (in French)

[6] Morsli, M., Kettab, R., Bali, A., and Fleureau, J. M. 2002. "Conception et Réalisation des Chaussées en Milieu Désertique (Design and Realization of Pavements in Desert Environment)." Presented at Journées Nationales de Géotechnique et de Géologie de l'Ingénieur, Nancy. (in French)

[7] Fenzy, E. 1966. "Particularité de la Technique Routière au Sahara (Particularity of the Technical Roads in the Sahara)." Revue génÉrale des Routes et Aérodromes 411: 57-71. (in French)

[8] Fenzy, E. 1970. L'état Actuel de la Technique Routière au Sahara (The Current State of the Technical Saharan Road). Technical report, Infrastructure Direction of the Saharan Organism, Ministry of Public Works, Algeria. (in French)

[9] CTTP (National Organization of Public Works). 2001. Catalogue de Dimensionnement des Chaussées Neuves (Catalog Sizing of New Pavements). Algérie: CTTP. (in French) 
[10] Struillou, L., and Alloul, B. 1984. "Valorisation Routière des Tufs d'Encroûtements en Algérie (Road Valorization of Crusts Tuffs in Algeria)." Bulletin of Engineering Geology and the Environment 2: 465-9. (in French)

[11] Khellou, A. 2011. "Modélisation du Comportement des Matériaux Sable Gyspso-Calcaire (Behavior Modeling of Gyspso-Limestone Sand Materials)." Magister thesis, Université Kasdi Merbah Ouargla. (in French)

[12] Ameraoui, Z. 2000. "Tufs d'Encroûtements: Utilisation Dans la Géotechnique Routière (Crusts Tuffs: Use in Geotechnical Road).” Magister thesis, National Polytechnic School. (in French)

[13] Cherrak, M., Morsli, M., Silhadi, K., and Bali, A. 2008. "Valorisation de 1'Utilisation des Tufs Calcaires en Techniques Routière (Use Valorization of Calcareous Tuff in Technical Road)." Presented at International Symposium Characterization and Modeling of Materials and Structures, Tizi Ouzou, Algeria. (in French)

[14] Goual, I., Goual, M. S., Abou-bekkr, N., and Taibi, S. 2011. "Effet de l'Ajout des Déchets de Carrière sur les Propriétés Physico-Mécaniques du Tuf de la Région de Laghouat-Algérie (Effect of Adding of Quarry Waste on the Physico-Mechanical Properties of the Tuff from the Laghouat Region, Algeria)." Annales du Bâtiments et des Tavaux Publics (Annals of Buildings and Public Works) 2: 33-41. (in French)

[15] Alloul, B. 1981. "Etude Géologique et Géotechnique des Tufs Calcaires et Gypseux d'Algérie en vue de Leur Valorisation Routière (Geological and Geotechnical Study of Calcareous and Gypsum Tuff in Algeria for Their Road Valorization)." Ph.D. thesis, University of Paris VI. (in French)

[16] Bendhia, M. H. 1983. "Les Tufs et Encroûtements Calcaires Dans la Construction Routière (Crusts and Calcareous Tuffs in Road Construction)." Doctor thesis, University of Paris VI. (in French)

[17] Mettai, M. 2009. "Caractérisation et Étude du Durcissement d'un Sable Gypseux de Ben Guencha, Dans le Domaine de la Géotechnique Routière (Characterization and Study of the Hardening of Gypsum Sand Ben Guencha in the Geotechnical Road Field)." Magister thesis, National Polytechnic School. (in French)

[18] Morsli, M., Bali, A., Bensaibi, M., and Gambin, M. 2007. "Etude du Durcissement d'un Tuf d'Encroûtements de Hassi-Messaoud, Algérie (Study of Hardening of Crusts Tuff from Hassi Messaoud, Algeria)." Revue Européenne de Génie-Civil (European Journal of Civil Engineering) 11: 1219-40. (in French)

[19] Hachichi, A., Boudia, M., and Mali, M. 2000. "Etude de l'Influence du Séchage et de l'Immersion sur la Résistance à la Compression Simple des Tufs Calcaires de la Région d'Oran (Study of the Drying and Immersion Influence on the Compressive Strength of Tuff of the Oran Region)." Presented at International Conference on Geo engineering, University of Science and Technology, Houari Boumerdienne, Algiers. (in French)

[20] Baslimane, B. 1994. Etude en Laboratoire $d u$ Comportement des Sables Gypseux. Ilème Séminaire : Les Techniques Routières Sahariennes (Laboratory Study of the Gypsum Sands Behavior. Second Seminary: The Technical Saharan Road). Beni Abbès: Comité de Liaison de la Route Transsaharienne. Recueil des communications, Séminaire international de Beni Abbès. (in French)

[21] Morsli, M. 2007. "Contribution à la Valorisation des Tufs d'Encroûtements en Technique Routière Saharienne (Contribution to the Valorization of Crusts Tuffs in Technical Saharan Road)." Ph.D. thesis, National Polytechnic School. (in French)

[22] Goual I., Goual M. S., Gueddouda, M. K., and Ferhat, A. 2008. "Effect of Treatment with Lime and Cement to the Mechanical Behavior of Calcareous Tuffs: For Use in Pavement Layers in the Region of Laghouat-Algeria." In Proceedings of International Conference on Construction and Building Technology, 101-12.

[23] Ould-Said, A. C., Havard, H., and Valin, C. 1995. "Terrassement Routiers Dans les Sables de Dunes de Mauritanie (Terrassement Road in Mauritania's Sand Dunes)." Bulletin de Liaison des Laboratoires des Ponts et Chausséees (Liaison Bulletin of Laboratories for Roads and Bridges) 199: 27-34. (in French)

[24] Bertozzi, J. 1989. “Comportement Mécanique d'un Sable Homométrique Stabilisé (Mechanical Behavior of Homométrique Sand Stabilized)." Revue Française de Géotechnique (French Geotechnical Journal) 60: 51-9. (in French)

[25] Chauvin, J. J. 1987. Les Sables, Guide Pratique d'Utilisation Routière (Sand, Practical Guide of Road Use). France: Institut des Sciences et des Techniques de l'Équipement et de l'Environnement Pour le Développement. (in French)

[26] Leghrieb, Y., Mitiche, R., Bentebba M. T., Djouhri, M., and Kriker, A. 2012. "The Manufacture of Raw Brick from the Saharan Sand Based Mortar of Ouargla (Located in the Septentrional Sahara, Algeria) from Use in Arid Regions." Arabian Journal for Science and Engineering 37 (8): 2149-61.

[27] Kettab, R., and Bali, A. 2011. "Caractéristiques et Durabilité d'un Béton de Sable de Dunes et d'un Béton Ordinaire Modifiés à la Poudrette de Caoutchouc (Characteristics and Sustainability of a Concrete Dunes Sand and Ordinary Concrete Modified by the Rubber Crumb)." Presented at 2nd International Congress on Technology and Durability of Concrete, Houari Boumerdienne, Algiers. (in French) 
[28] Ahmed, T. 2009. "Contribution à la Valorisation du Sable de Dune de l'Erg Occidental (Contribution to the Dune Sand Valorization in the Occidental Erg)." Doctor thesis, Université de Toulouse. (in French)

[29] Kettab, R. 2007. "Contribution à la Valorisation du Sable de Dune (Contribution to the Dune Sand Valorization)." Ph.D. thesis, National Polytechnic School. (in French)

[30] Kettab, R., Bali, A., and Alliche, A. 2007. "Modified Sand Concrete for Waste Management Revue." International Journal of Nuclear Energy Science and Technology 3 (1): 63-75.

[31] Benna, Y., Guettache, B., Bedjou, S., Ait-Said, S., and Brara, A. 2006. "Valorisation des Sables de Dune, Propriétés Physico-Mécanique des Mortiers à Base de Sables de Dune (Dune Sands Valorization Physical and Mechanical Properties of Dune Sand Mortars).” Presented at 3rd Workshop on Technologies of Concrete: Concrete, the Traditional to the High Performance, Algiers. (in French)

[32] Benabed, B., Azzouz, L., and Damene, Z. 2005. "Comportement Mécanique et Durabilité des Mortiers à Base de Sable de Dune (Mechanical Behavior and Sustainability of Dune Sand Mortars)." Presented at Mediterranean Symposium on Materials, Algeria. (in French)

[33] Gueddouda, M. K., Abou-Bekr, N., Taibi, S., and Arab, R. 2011. "Hydric Behavior of Dune Sand-Bentonite Barrier." Presented at Meetings Geosynthetics, Tours, France. (in French)

[34] Mitiche, R., Morsli, M., Boutemeur, R., and Laakel, A. 2009. "Stabilisation Physico-Chimique des Sols Fins au Lignosulfonate (Physico-Chemical Fine Soil Stabilization by Lignosulfonate)." Presented at International Workshop Innovation and Valorization in Civil Engineering, Tunisia. (in French)
[35] Azzouz, L., Bouchicha, M., and Khenfer, M. 2001. "Stabilisation Physico-Chimique d'un sol Sableux-AJOT (Physico-Chemical Sandy Soil Stabilization-AJOT)." International Publication 13 (1): 47-53. (in French)

[36] Freer-Hewish, R. J., Ghataora, G. S., and Niazi, Y. 1999. "Stabilization of Desert Sand with Cement Kiln Dust plus Chemical Additives in Desert Road Construction." In Proceedings of the Institution of Civil Engineers 135 (1): 29-36.

[37] Al-Abdul Wahhab, H. I., and Asi, I. M. 1997. "Improvement of Marl and Dune Sand for Highway Construction in Arid Areas." Building and Environment 32 (3): 271-9.

[38] Fumet, P. 1959. "Chaussées en Sable Gypseux et en Sables Stabilisés Chimiquement (Pavements Gypsum Sand and Sand Chemically Stabilized)." Revue Générale of Roads and Aerodromes 329: 169-78. (in French)

[39] Dhia, M. H. B. 1998. Quelques Particularités de l'Utilisation du Sable de Dune en Construction Routière en Milieu Saharien (Some Peculiarities of the Use of Dune Sand in Road Construction in Saharan Environment). Bulletin de Liaison du Laboratoire Pont et Chaussée. (in French)

[40] Colombier, G. 1988. Tufs et Encroûtements Calcaires: Utilisations routièRes (Tuff and Calcareous Crusts: Road Uses). France: Institut des Sciences et des Techniques de l'Équipement et de l'Environnement pour le Développement. (in French)

[41] Holtz, R., and Kovaks, W. 1996. Introduction à la Géotechnique, Edition de l'Ecole Nationale Polytechnique de Montreal (Introduction to Geotechnical Edition of the National Polytechnic School of Montreal). Montreal: Edition de l'Ecole Nationale Polytechnique de Montreal. (in French) 